\title{
Teaching Video NeuroImages: Cold-induced laryngeal pseudomyotonia in Isaacs syndrome
}

Hugo Morales-Briceño, MD, Jose Renan Perez, MD, Bettina Balint, MD, and Victor S.C. Fung, PhD, FRACP

Neurology ${ }^{\circledR}$ 2019;92:e2734. doi:10.1212/WNL.0000000000007613

A 36-year-old man developed progressive limb pain, excessive sweating, and muscle cramps. He described transient strained voice only after drinking cold water (video 1). Examination revealed generalized myokymia and pseudomyotonia. EMG revealed multiple spontaneous, continuous high frequency doublet and triplet motor unit discharges. Nerve conduction studies and chest CT scan were normal. CASPR2 and LGI1 antibodies were negative. Autoimmune, paraneoplastic, and other etiologies were excluded clinically as well as through additional serologic (or blood) testing and imaging. Symptoms resolved completely after IV immunoglobulin and carbamazepine for treatment of pain.

Painful cramps, myokymia, hyperhidrosis, and pseudomyotonia are cardinal features of Isaacs syndrome. Isaacs syndrome is a peripheral nerve hyperexcitability disorder often associated with antibodies targeting components of voltage-gated potassium channels; however, $<50 \%$ of patients are antibody-positive. ${ }^{1}$ Bulbar involvement is an uncommon feature, and our patient exhibits cold-induced pseudomyotonia, which has not been previously described in the literature. $^{2}$

\section{Author contributions}

H. Morales-Briceño and J. Renan Perez drafted the manuscript and videotape. B. Balint and V.S.C. Fung examined the video of the patient and provided critical review of the manuscript.

\section{Acknowledgment}

The authors thank Dr. Josep Dalmau (Universitat de Barcelona, Spain) for performing the antibody analysis.

\section{Study funding}

No targeted funding reported.

\section{Disclosure}

The authors report no disclosures relevant to the manuscript. Go to Neurology.org/ $\mathrm{N}$ for full disclosures.

\section{References}

1. Vincent A, Pettingill P, Pettingill R, et al. Association of leucine-rich glioma inactivated protein 1, contactin-associated protein 2, and contactin 2 antibodies with clinical features and patient-reported pain in acquired neuromyotonia. JAMA Neurol 2018;75:1519-1527.

2. Hart IK, Maddison P, Newsome-Davis J, Vincent A, Mills KR. Phenotypic variants of autoimmune peripheral nerve hyperexcitability. Brain 2002;125:1887-1895.

\author{
Correspondence \\ Dr. Fung \\ vscfung@ozemail.com.au
}

MORE ONLINE

○ Video

$\rightarrow$ Teaching slides

links.lww.com/WNL/

A896

From the Movement Disorders Unit, Neurology Department (H.M.-B., V.S.C.F.), Westmead Hospital, Australia; Hospital de Especialidades (J.R.P.), Centro Médico Nacional “Siglo XXI," Instituto Mexicano del Seguro Social, Tamps, Mexico; Sobell Department of Motor Neuroscience and Movement Disorders (B.B.), UCL Institute of Neurology, London, UK; Department of Neurology (B.B.), University Hospital, Heidelberg, Germany; and Sydney Medical School (H.M.-B., V.S.C.F.), University of Sydney, Australia.

Go to Neurology.org/N for full disclosures. 


\section{Neurology}

\section{Teaching Video NeuroImages: Cold-induced laryngeal pseudomyotonia in Isaacs syndrome}

Hugo Morales-Briceño, Jose Renan Perez, Bettina Balint, et al. Neurology 2019;92;e2734

DOI 10.1212/WNL.0000000000007613

\section{This information is current as of June 3, 2019}

\section{Updated Information \&} Services

References

Subspecialty Collections

Permissions \& Licensing

Reprints including high resolution figures, can be found at: http://n.neurology.org/content/92/23/e2734.full

This article cites 2 articles, 0 of which you can access for free at: http://n.neurology.org/content/92/23/e2734.full\#ref-list-1

This article, along with others on similar topics, appears in the following collection(s):

Autoimmune diseases

http://n.neurology.org/cgi/collection/autoimmune_diseases Neuropathic pain

http://n.neurology.org/cgi/collection/neuropathic_pain

Information about reproducing this article in parts (figures,tables) or in its entirety can be found online at:

http://www.neurology.org/about/about_the_journal\#permissions

Information about ordering reprints can be found online:

http://n.neurology.org/subscribers/advertise

Neurology ${ }^{\circledR}$ is the official journal of the American Academy of Neurology. Published continuously since 1951, it is now a weekly with 48 issues per year. Copyright @ 2019 American Academy of Neurology. All rights reserved. Print ISSN: 0028-3878. Online ISSN: 1526-632X.

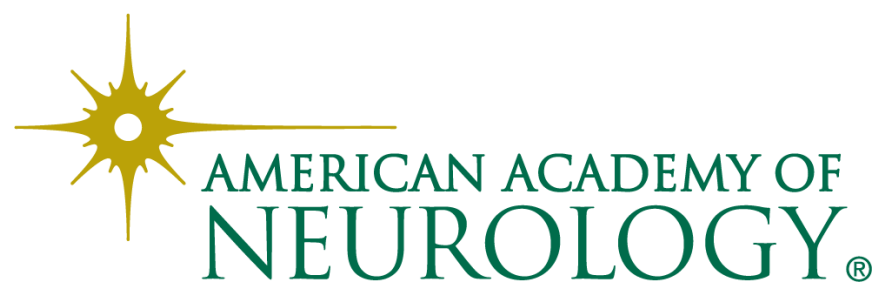

